\begin{tabular}{ll|} 
DOI 10.31558/2307-2318.2020.4.2 & \\
УДК 338.43:339 & \\
JEL: F01, Q10
\end{tabular}

Варламова М.Л., кандидат економічних наук, Донецький національний університет імені Василя Стуса m.varlamova@donnu.edu.ua ORCID: 0000-0001-7111-1136

Данилишина A.O.,

Донецький національний університет імені Василя Стуса anastasiastepantsova@gmail.com

\title{
РОЗВИТОК АПК УКРАЇНИ В КОНТЕКСТІ ГЛОБАЛЬНОЇ ПРОДОВОЛЬЧОЇ БЕЗПЕКИ
}

У статті досліджено розвиток АПК України в контексті глобальної продовольчої безпеки. Проаналізовані загальні тенденції, щцо характеризують стан глобальної продовольчої безпеки. Окреслено значення АПК в економічі України та здійснено аналіз основних тенденщій його розвитку. Виявлено основні напрями розвитку агропромислового комплексу, що сприяють підвищенню конкурентоспроможності сільськогосподарської продукиії та зміцненню орієнтації сільського господарства, що вимагає від керівництва галузі вміння бачити перспективи його розвитку, приймати грамотні управлінські рішення в сучасних ризикованих умовах господарювання.

Ключові слова: агропромисловий комплекс, інвестиції, інвестиційна активність, інвестиційна привабливість, ризики, продовольча безпека, регулювання, ефективність.

Рис. -6, Табл. -1 , Літ. -6

Постановка проблеми. На сьогоднішній день, в умовах існування глобальної продовольчої проблеми, перед кожною державою стоїть завдання забезпечення населення необхідною кількістю продовольства, а також значне збільшення його доступності в довгостроковій перспективі. Відповідно, це дає поштовх країнам до розвитку галузі АПК через інвестиції та науково-практичні розробки у цій сфері.

Акцентуючи увагу на тому, що Україна - аграрна країна, АПК держави сьогодні потерпає від нестачі інвестицій, зважаючи на необхідність переоснащення галузі та втілення інноваційних технологій. Також існує ряд факторів, які чинять значний вплив на інвестиційні привабливість та клімат аграрної промисловості України.

Аналіз останніх досліджень та публікацій. Дослідженням питань економіки сільськогосподарської праці, підвищення інвестиційної привабливості АПК та продуктивності підпримств займалася значна кількість вчених: Бланк I.О., Геєць В.М., Данилишин Б.М., Дієсперов В. С. [2], Вітвіцький В. В. [4] та інші. Проте тривалий процес реформування галузі та досягнення нових результатів аграріями України показують доцільність та потребу у подальшому дослідженні та оцінки інвестиційної привабливості АПК України.

Метою дослідження $є$ аналіз стану розвитку АПК в контексті продовольчої безпеки. Методологія роботи включає в себе застосування загальних і спеціальних 
методів пізнання, що дозволяють оцінити соціально-економічний стан агропромислового комплексу, в тому числі аналізу, синтезу і зіставлення.

Виклад основного матеріалу. Згідно 3 дослідженнями Продовольчої та сільськогосподарської організації ООН (ФАО) від голоду страждають близько 690 млн чоловік, що складає 8,9\% населення планети, причому за останній рік спостерігається збільшення на 10 мільйонів, а за п'ять років - майже на 60 мільйонів [1].

Найбільше число тих, хто недоїдає - 381 млн - як і раніше, припадає на Азію. В Африці $з$ проблемою недостатності харчування зіткнулися 250 млн чоловік, і їх кількість зростає швидше, ніж в будь-якому іншому регіоні світу. Тенденція до зростання відзначається i за показником поширеності гострого відсутності продовольчої безпеки, який також відображає масштаби голоду. У 2019 з гострою відсутністю продовольчої безпеки зіткнулися близько 750 млн чоловік, або майже кожен десятий житель планети [1].

В цілому з помірною або гострою відсутністю продовольчої безпеки, згідно 3 оцінками, в 2019 році стикалися два мільярди людей, позбавлених постійного доступу до достатньої кількості безпечної та поживної їжі. Очікується, що пандемія ще більше позначиться на негативних тенденціях продовольчої безпеки і харчування в світі. Осередки відсутності продовольчої безпеки можуть виникнути навіть в тих країнах і серед тих груп населення, які зазвичай цій проблемі не схильні. Згідно з попередньою оцінкою, в 2020 році в результаті пандемії, в залежності від економічних показників, загальна кількість тих, хто недоїдає в світі може збільшитися на 83-132 млн осіб [1].

Таким чином, сьогодні як ніколи гостро стоїть проблема продовольчої безпеки. Вирішення глобальної проблеми продовольчої безпеки можливо за рахунок як спільних дій світової спільноти, так і за рахунок розвитку АПК кожної країни. Агропромисловий комплекс (АПК) - це сукупність галузей народного господарства, які пов'язані 3 розвитком сільського господарства, обслуговуванням його виробництва і доведенням сільськогосподарської продукції до споживача. [2]. АПК - один з найбільш великих і значущих міжгалузевих секторів національної економіки. Зниження залежності країни в продовольчій сфері передбачає розробку загальної концепції і програми національної безпеки країни [3].

Україна має унікальні можливості. Із 60 млн га території нашої держави понад $70 \%$ складають сільгоспугіддя. За площею чорноземів Україна займає четверте місце в світі після Росії, США і Китаю. Для виміру продовольчої безпеки на рівні держави використовують глобальний індекс продовольчої безпеки, який розглядає основні проблеми доступності та якості продовольства в 113 країнах. За рейтингом 2019 року Україна посіла 76 місце, з індексом 57,1 (рис. 1) [4].

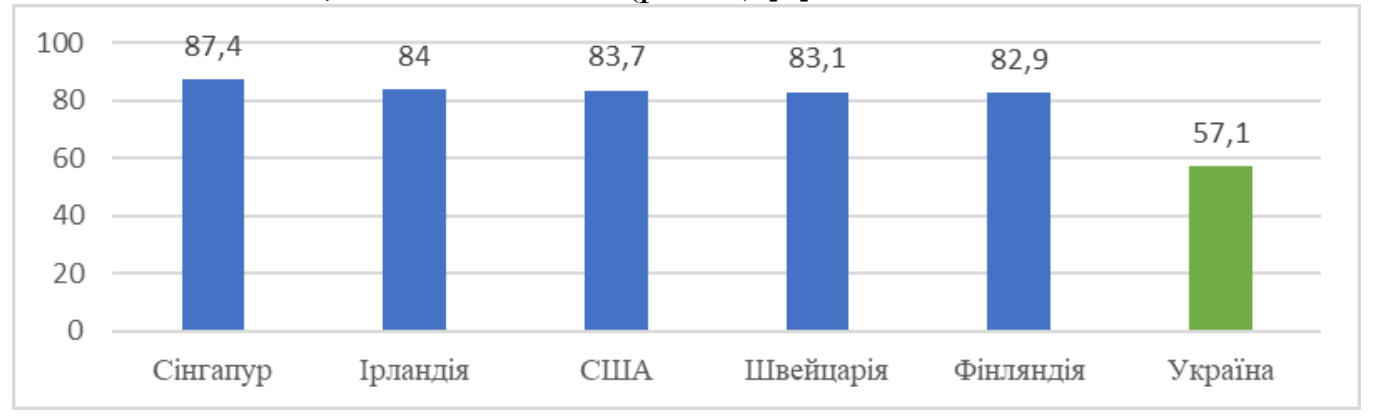

Рисунок 1. Індекс продовольчої безпеки, 2019 р. [4] 
Таким чином, незважаючи на можливості України, рівень продовольчої безпеки знаходиться на порівняно низькому рівні. На це впливає ряд чинників, зокрема, рівень розвитку АПК.

Аналіз стану АПК України на основі даних Державної служби статистики України показав, що сільське господарство (включаючи рибальство) входить в 10 провідних секторів національний економіки за часткою в ВВП - 9-е місце (рис. 2) [5].

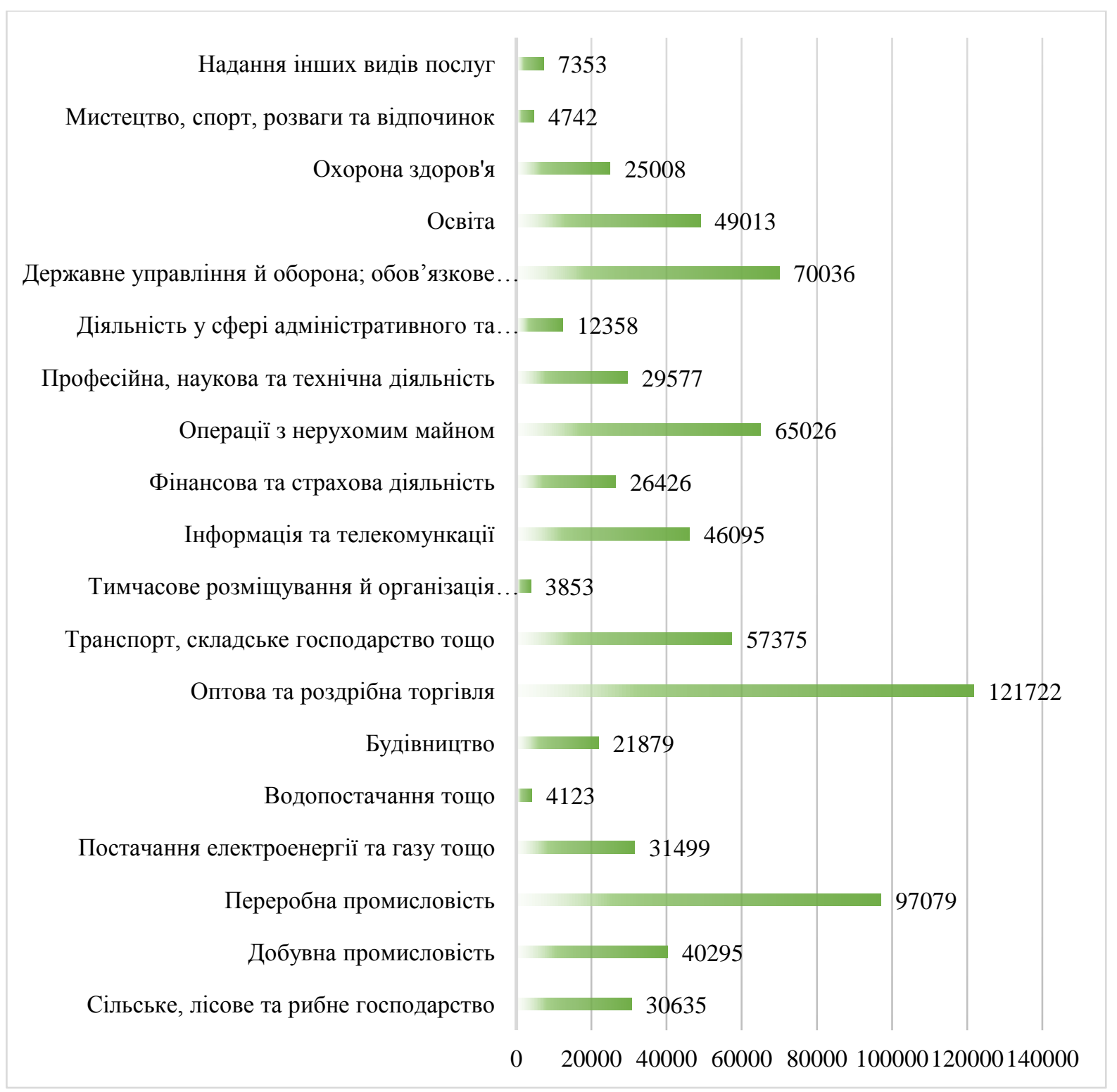

Рисунок 2. Виробнича структура ВВП за 2020 рік (млн. грн.) [5]

Загалом обсяги продукції рослинництва ростуть, починаючи з 1999 року (рис. 3). Однак в 2008 році спостерігається спад обсягу ринку продукції рослинництва, що можна пояснити сформованими кризовими умовами в цей період. Але наразі ситуація на ринку більш-менш стабілізувалася. Щодо тваринництва, то спостерігаємо значний спад обсягів з 1991 року по 1997, що можна підтвердити нестабільною ситуацією в країні у той період. Загалом у період з 1997 р. по 2019 р. умови стабільні. 


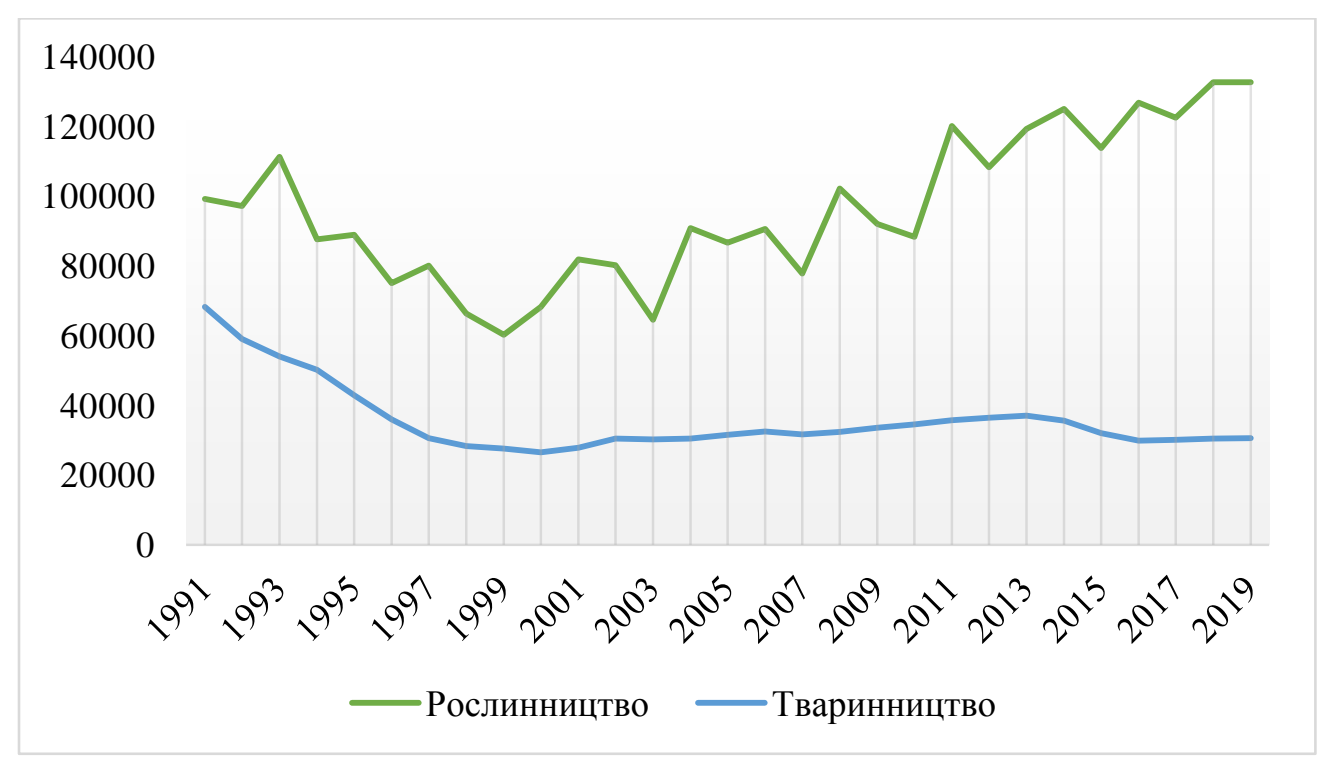

Рисунок 3. Обсяг сільського господарства, тис. т. [5]

Динаміка цін на сільськогосподарському ринку за основними блоками рослинництво і тваринництво - демонструє істотні коливання обох блоків (рис. 4).

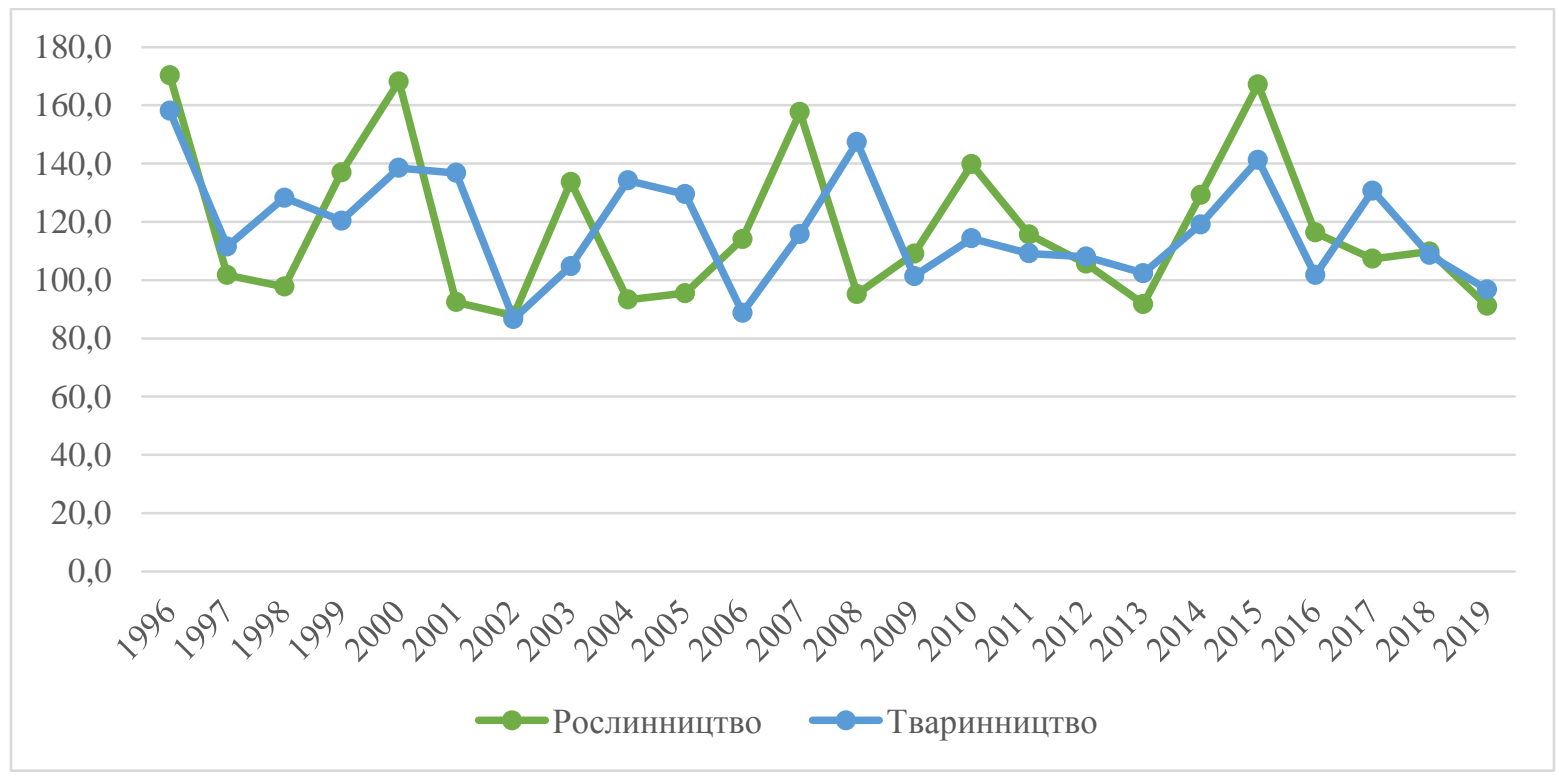

Рисунок 4. Індекси цін реалізованої підприємствами продукції сільського господарства (\% до попереднього року) [5]

Інвестиційна привабливість підприємств агропромислового комплексу - це їх здатність викликати комерційний і інший інтерес у потенційних інвесторів. Сільське господарство, як було зазначено вище, має ряд специфічних особливостей, які роблять сильний вплив на інвестиційну привабливість як окремих підприємств, так і галузі в цілому.

На сучасному етапі розвитку найбільш привабливими з точки зору інвестора $є$ високоприбуткові обробні галузі економіки. У зв'язку з цим, окремі галузі часто 
недоотримують інвестиції. До таких галузей відноситься і сільське господарство (див. табл. 1).

Таблиця 1

Капітальні інвестиції за видами економічної діяльності за 2015-2019 роки [5]

\begin{tabular}{|c|c|c|c|c|c|}
\hline & 2015 & 2016 & 2017 & 2018 & 2019 \\
\hline Усього & 273116,4 & 359216,1 & 448461,5 & 578726,4 & 623978,9 \\
\hline $\begin{array}{l}\text { Сільське господарство, лісове } \\
\text { господарство та рибне } \\
\text { господарство }\end{array}$ & 30154,7 & 50484,0 & 64243,3 & 66104,1 & 59129,5 \\
\hline Промисловість & 87656,0 & 117753,6 & 143300,0 & 199896,0 & 254196,2 \\
\hline Будівництво & 43463,7 & 44444,0 & 52176,2 & 55993,9 & 62346,6 \\
\hline $\begin{array}{l}\text { Оптова та роздрібна торгівля; } \\
\text { ремонт автотранспортних } \\
\text { засобів і мотоциклів }\end{array}$ & 20662,9 & 29956,8 & 33664,8 & 51817,6 & 44173,7 \\
\hline $\begin{array}{l}\text { Транспорт, складське } \\
\text { господарство, поштова та } \\
\text { кур'єрська діяльність }\end{array}$ & 18704,0 & 25107,8 & 37943,5 & 50078,3 & 43792,8 \\
\hline $\begin{array}{l}\text { Тимчасове розміщування й } \\
\text { організація харчування }\end{array}$ & 1393,1 & 1477,9 & 2133,5 & 2675,1 & 2832,2 \\
\hline $\begin{array}{l}\text { Інформація та } \\
\text { телекомунікації }\end{array}$ & 22975,0 & 15651,2 & 18395,2 & 29884,9 & 21063,4 \\
\hline $\begin{array}{l}\text { Фінансова та страхова } \\
\text { діяльність }\end{array}$ & 6448,0 & 7678,7 & 8055,3 & 10652,3 & 11246,3 \\
\hline Операції з нерухомим майном & 11899,0 & 19665,0 & 22505,6 & 27556,8 & 28147,2 \\
\hline $\begin{array}{l}\text { Професійна, наукова та } \\
\text { технічна діяльність }\end{array}$ & 4065,2 & 6579,4 & 7965,3 & 10798,2 & 11912,4 \\
\hline $\begin{array}{l}\text { Діяльність у сфері } \\
\text { адміністративного та } \\
\text { допоміжного обслуговування }\end{array}$ & 6535,2 & 10009,2 & 12747,3 & 11837,8 & 11741,1 \\
\hline $\begin{array}{l}\text { Державне управління й } \\
\text { оборона; обов'язкове } \\
\text { соціальне страхування }\end{array}$ & 13942,4 & 22380,8 & 32843,9 & 44597,8 & 54305,5 \\
\hline Освіта & 1540,1 & 2257,3 & 3492,5 & 4460,0 & 4788,7 \\
\hline $\begin{array}{l}\text { Охорона здоров'я та надання } \\
\text { соціальної допомоги }\end{array}$ & 2367,2 & 4479,0 & 6708,3 & 8138,8 & 9484,6 \\
\hline $\begin{array}{l}\text { Мистецтво, спорт, розваги та } \\
\text { відпочинок }\end{array}$ & 1044,3 & 969,9 & 1649,2 & 3663,2 & 4146,2 \\
\hline Надання інших видів послуг & 265,6 & 321,5 & 637,6 & 571,6 & 672,5 \\
\hline
\end{tabular}

В даний час агропромисловий комплекс $є$ все менш привабливим для інвесторів (рис. 5). Спостерігається його технічне та технологічне відставання, варто відзначити і невисокий матеріально-технічний і виробничий потенціал галузі. Все це позначається на низькій конкурентоспроможності вітчизняної сільськогосподарської продукції, насиченості продовольчого ринку країни продуктами імпортного походження [5]. 


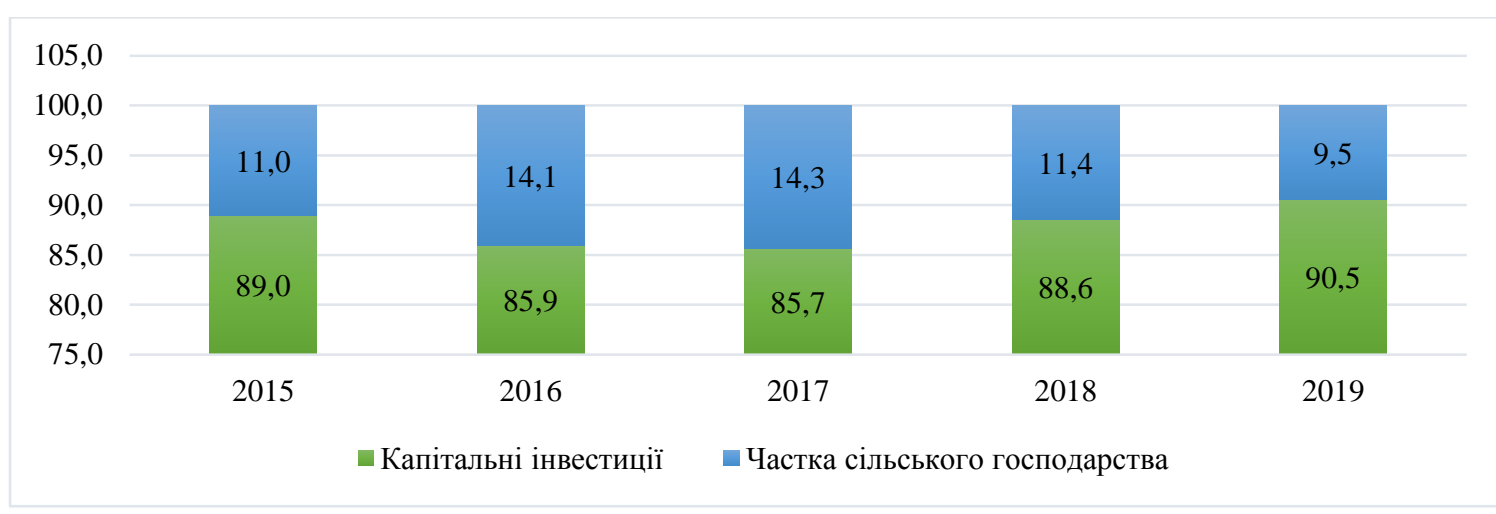

Рисунок 5. Частка інвестицій в сільське господарство в загальній структурі інвестицій в основний капітал, \% [5]

Результати соціологічного опитування, проведеного компанією «Делойт», дозволяють виділити ряд ключових проблем, 3 якими стикаються компанії агропромислового комплексу України в процесі своєї діяльності. Зокрема, до них можна віднести: недосконалість державного регулювання галузі, недостатню державну підтримку і фінансування, низький виробничо-технічний потенціал, валютні ризики, непривабливість даного бізнесу для зовнішніх інвесторів, геополітичні ризики, негнучкість податкової системи та інші (рис. 6) [6].

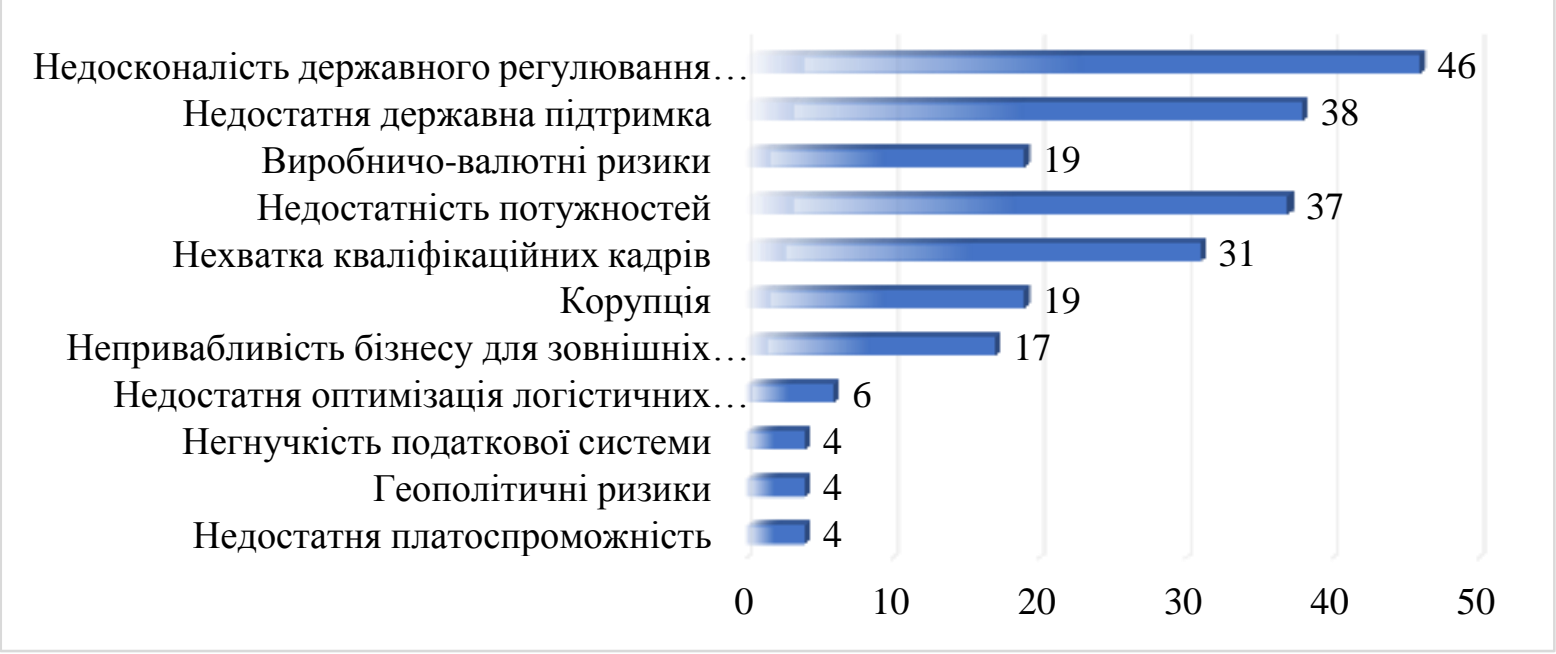

Рисунок 6. Рейтинг проблем бізнесу АПК в 2019 році [6]

Незважаючи на те, що непривабливість агропромислового бізнесу для зовнішніх інвесторів не входить в число п'яти найсерйозніших проблем, іiі значимість не повинна бути занижена.

Фактори, що впливають на інвестиційну активність АПК, можна розглядати на декількох рівнях: на рівні країни, регіону, підприємства. На рівні країни на АПК впливають такі фактори, як ступінь розвитку в ньому ринкових механізмів, розвиток його інвестиційної інфраструктури, рівень державного регулювання, природнокліматичні ризики сільськогосподарського бізнесу, ступінь інтеграції вітчизняного агропромислового комплексу в світову економіку, а також режим податкового, 
митного, тарифного сприяння виробництву продукції агропромислового комплексу та інші.

На рівні регіону діють наступні фактори: регіональна інвестиційна інфраструктура, географічне положення регіону, регіональна інвестиційна законодавча база, рівень конкуренції, ступінь монополізації галузі та інші.

На рівні окремого підприємства АПК мають значення ступінь технічної оснащеності виробництва, наявність інвестиційної та інноваційної стратегії розвитку підприємства, рівень конкурентоспроможності його продукції, забезпеченість кваліфікованими кадрами, організаційно-правова форма підприємства, його фінансове стан (платоспроможність), а також частка ринку, виробничий і технічний потенціал підприємства і т. д.

Висновки. Подальший розвиток агропромислового комплексу в контексті продовольчої безпеки і підвищення ефективності діяльності окремих підприємств можливий за рахунок посилення інвестиційно-інноваційної діяльності. Наразі іiі реалізація потребує державної підтримки. В роботі показано, що до основних напрямів державного регулювання інвестиційної діяльності в агропромисловому комплексі можна віднести: створення сприятливих організаційно-економічних умов для інвестування агропромислового виробництва 3 метою підвищення інвестиційної привабливості сільського господарства, залучення додаткових інвестицій в галузі агропромислового комплексу; прямий i опосередкований участь держави в інвестиційній діяльності аграрного сектора 3 метою поліпшення структури агропромислового виробництва, збільшення прибутковості, підтримки виробничої і соціально-побутової інфраструктури села, залучення інвесторів на принципах співфінансування (в тому числі за рахунок розробки та реалізації програм конвертації заощаджень населення в інвестиційні ресурси економіки); інші форми державного регулювання і захисту інтересів сільськогосподарських товаровиробників та інвесторів. Посилення ефективності розвитку АПК України позитивно впливатиме на продовольчу безпеку країни.

\section{СПИСОК ВИКОРИСТАНИХ ДЖЕРЕЛ}

1. ФАО, МФСР, ЮНИСЕФ, ВПП и ВОЗ (2020). Положение дел в области Продовольственной безопасности и питания в мире 2020. C. 320. URL: http://www.fao.org/documents/card/en/c/ca9692ru

2. Диесперов, В. С. (2016). Экономика сельскохозяйственного труда. Экономика АПК. С. 110-117.

3. Вітвіцький, В. В. (2016). Теоретичні аспекти визначення продуктивності праці сільськогосподарських підприємств. Економіка АПК. С. 26-34.

4. The Economist Intelligence Unit. Country rankings 2019. Performance of countries based on their 2019 food security score. URL: https://foodsecurityindex.eiu.com/Index

5. Офіційний сайт Державної служби статистики України. URL: http://ukrstat.gov.ua

6. Deloitte Touche Tohmatsu Limited home page. URL: https://www2.deloitte.com/ua/uk.html.

\section{REFERENCES}

1. FAO, MFSR, YuNYSEF, VPP y VOZ (2020). Polozhenye del v oblasty Prodovolstvennoi bezopasnosty y pytanyia v myre 2020. S. 320. URL: http://www.fao.org/documents/card/en/c/ca9692ru 
2. Dyesperov, V. S. (2016). Эkonomyka selskokhoziaistvennoho truda. Эkonomyka APK. S. 110-117.

3. Vitvitskyi, V. V. (2016). Teoretychni aspekty vyznachennia produktyvnosti pratsi silskohospodarskykh pidpryiemstv. Ekonomika APK. S. 26-34.

4. The Economist Intelligence Unit. Country rankings 2019. Performance of countries based on their 2019 food security score. URL: https://foodsecurityindex.eiu.com/Index

5. Ofitsiinyi sait Derzhavnoi sluzhby statystyky Ukrainy. URL: http://ukrstat.gov.ua

6. Deloitte Touche Tohmatsu Limited home page. URL: https://www2.deloitte.com/ua/uk.html.

Варламова М.Л., кандидат экономических наук, Донецкий национальный университет имени Васыля Стуса, ORCID: 0000-0001-7111-1136

m.varlamova@donnu.edu.ua

Данилишина А.А., Донецкий национальный университет имени Васыля Стуса

anastasiastepantsova@gmail.com

РАЗВИТИЕ АПК УКРАИНЫ В КОНТЕКСТЕ ГЛОБАЛЬНОЙ ПРОДОВОЛЬСТВЕННОЙ БЕЗОПАСНОСТИ

В статье исследовано развитие АПК Украины в контексте глобальной продовольственной безопасности. Проанализированы общие тенденщии, характеризующие состояние глобальной продовольственной безопасности. Определень значения АПК в экономике Украины и осуществлен анализ основных тенденций его развития. Выявлены основныле направления развития агропромышленного комплекса, способствуют повышению конкурентоспособности сельскохозяйственной продукции и укреплению ориентации сельского хозяйства, требует от руководства области умение видеть перспективы его развития, принимать грамотнье управленческие решения в современных рискованных условиях хозяйствования.

Ключевье слова: агропромышленный комплекс, инвестиции, инвестиционная активность, инвестиционная привлекательность, риски, продовольственная безопасность, регулирование, эффективность.

M. Varlamova, PhD in Economics, Vasyl Stus DonNU, ORCID: 0000-0001-7111-1136 m.varlamova@donnu.edu.ua

A. Danylyshyna, Vasyl Stus DonNU

anastasiastepantsova@gmail.com

DEVELOPMENT OF AGRICULTURE OF UKRAINE IN THE CONTEXT OF GLOBAL FOOD

SECURITY

The article examines the development of Ukraine's agro-industrial complex in the context of global food security. The general tendencies characterizing the state of global food security are analyzed. The importance of agro-industrial complex in the economy of Ukraine is outlined and the analysis of the main tendencies of its development is carried out. The main directions of agro-industrial complex development are revealed, which contribute to increasing the competitiveness of agricultural products and strengthening the orientation of agriculture, which requires the management of the industry to see the prospects of its development, make competent management decisions in modern risky business conditions.

Keywords: agro-industrial complex, investments, investment activity, investment attractiveness, risks, food security, regulation, efficiency. 